Dissertation

\title{
Four Studies on Antitrust Enforcement and Foreign Investment Activities
}

\author{
Nan Zhang ${ }^{1} \oplus^{a}$ \\ ${ }^{1}$ California State University Stanislaus, USA \\ Keywords: foreign direct investment, business/government interaction and relationships, panel data models, antitrust policy, MNE-host country \\ relationships
}

https://doi.org/10.46697/001c.30111

\section{AIB Insights}

Vol. 21, Issue 4, 2021

\begin{abstract}
Motivated by the potential for antitrust policy to contribute to de-globalization by deterring FDI, my dissertation studies how MNEs respond to the increased antitrust enforcement when engaging in foreign investment activities after the global financial crisis of 2008. I employ multi-level data on U.S. antitrust enforcement (industry-level), inward-FDI (industry-level), cross-border M\&As (firm-level), and Greenfield FDI (firm-level) in the U.S. markets over 2002-2017 for empirical testing. The findings support my theoretical priors that U.S. antitrust enforcement increases after the global financial crisis, deters aggregated inward-FDI and foreign-acquirer-presence in local M\&A markets, and attracts Greenfield FDI.
\end{abstract}

\section{BIG QUESTION}

How do MNEs respond to the increased antitrust enforcement when engaging in foreign investment activities after the global financial crisis of 2008 ?

\section{INTRODUCTION}

What drives de-globalization? How can the policy factors affect cross-national investing activities? In other words, how do MNEs respond to the increased antitrust enforcement when engaging in foreign investment activities after the global financial crisis of 2008? My dissertation attempts to answer these questions by explaining the influence of antitrust policy on foreign investments, which contributes to the change of the global economic landscape after the financial crisis of 2008.

Many assert that global processes determine our social life. However, attitudes toward globalization are changing. Global economy is threathen by radical doubts about benefits of globalization and backlashes against immigration, trade agreements, and multinational enterprises. Prominant examples are the U.K.'s withdrawal from the European Union and a U.S. president's explicit “America first" agenda. The main architects of globalization (U.S. and U.K.) now appear to be reversing direction and contributing to de-globalization. Covid-19 has also triggered a dramatic decline in global trade and foreign investments (Antràs, 2021).

Skepticism toward globalization has erected barriers that both slow and decrease global commerce. Antitrust policies
- historically used to regulate domestic competition (Porter, 1998) - are now used to inhibit foreign investment. Rising antitrust cases suggest increasing economic nationalism. For example, the new Chinese antitrust agency prohibited Coca-Cola's acquisition of a local juice company, which was reportedly taken to protect an indigenous firm (Zhang \& Zhang, 2010). Recently, the European Commission (EC) levied substantial fines on U.S. high-tech firms for anti-competitive practices.

Responding to calls to systematic study antitrust enforcement on foreign investment, my dissertation addresses the following research questions: (1) How has antitrust enforcement changed after the global financial crisis of 2008?; (2) How does antitrust enforcement affect inward FDI?; (3) How does antitrust enforcement affect foreign Mergers and Acquisitions (M\&A) in local markets?; and (4) How does antitrust enforcement affect cross-border horizontal M\&As, non-horizontal M\&As, and Greenfield FDI differently?

\section{(1) HOW HAS ANTITRUST ENFORCEMENT CHANGED AFTER THE GLOBAL FINANCIAL CRISIS OF 2008?}

My dissertation firstly examines how antitrust enforcement has changed after the global financial crisis of 2008. Globalization produces economic winners and losers, and the narrow distribution of gains from international openness has exacerbated the costs to the losers. Increased inequality generates nationalism, angst, and uncertainty, which drives

\footnotetext{
a Ph.D. awarded by University of Illinois at Urbana-Champaign, USA (May 2020)

Dissertation title: Four Studies on Antitrust Enforcement and Foreign Investment Activities
} 
the backlash against globalization (Kobrin, 2017).

Scholars and pundits have observed a rise in recent years of antitrust cases, which potentially indicate increased economic nationalism. The traditional skepticism exhibited by 'corporatist' nation-states toward more pluralist and open antitrust policy to inward FDI in combination with recent examples of economic nationalism (e.g., the EU and China) has led to some sobering assessments. In particular, observers have expressed concern that protectionist antitrust enforcement reflects a growing skepticism about the benefits of an open policy toward foreign investments. The greater concern is this growing skepticism and protectionist enforcement of antitrust policy may ultimately result in diminished cross-border investment flows and reduced globalization of commerce.

Given the potential deterrence effect of antitrust enforcement on FDI, it is reasonable to believe if antitrust enforcement increases after the global financial crisis of 2008, it may contribute to de-globalization. ${ }^{1}$ I conjecture that the strictness of antitrust has increased in the postfinancial-crisis years, suggesting antitrust enforcement in the contemporary cross-national context can partly contribute to backlashes against globalization (Kobrin, 2017). Specifically, U.S. antitrust generally becomes stricter when (1) economic downturns manifest; (2) antitrust officials are unencumbered by a wave of transaction activity; and (3) the Presidency resides with the Democratic Party. ${ }^{2}$

I employ sector-level data on antitrust scrutiny covering 57 industries from 2002 to 2016. The empirical results indicate U.S. antitrust enforcement has substantially increased after the global financial crisis. Given the potential deterrence effects of antitrust policy on foreign investments (studied in later essays), this stricter enforcement may contribute to de-globalization. Accordingly, this increased strictness brings policy implications as one of the main challenges for the future of cross-border investments. Particularly, MNEs who target in U.S. market would fully consider the more stringent antitrust enforcement after the global financial crisis of 2008 .

\section{(2) HOW DOES ANTITRUST ENFORCEMENT AFFECT INWARD FDI AT AN AGGREGATED LEVEL?}

Essays 2, 3, and 4 focus on how antitrust enforcement can affect different foreign-investment activities. Nations generally promote antitrust policy to secure domestic welfare benefits; though, there is concern that antitrust policy has been increasingly employed in a protectionist manner in line with increasing skepticism toward globalization.

The second essay examines how antitrust enforcement deters inward-FDI activity. Cross-border investments tend to be more horizontal and related in nature as compared to domestic investments. U.S. antitrust authorities have long viewed horizontal transactions as anti-competitive, whereas non-horizontal transactions rarely involve anticompetitive effects (Viscusi, Vernon, \& Harrington, 1995). Accordingly, vigorous antitrust enforcement may disproportionately impair inward cross-border investments due to the prevailing horizontal nature. Moreover, antitrust policy represents a direct institutional counter to MNE's marketpower incentives and therefore deters cross-border horizontal M\&As (Brewer, 1993). Lastly, navigating host nation's antitrust review involves direct and indirect transaction costs that slow the onset of FDI. Hence hostcountry antitrust enforcement increases transaction costs and uncertainty that deter MNE's willingness to engage in FDI.

The panel-data empirical results - from U.S. sector-level data covering 53 industries over 2002-2017 - indicate increased antitrust enforcement deters inward-FDI stocks. It suggests antitrust policy represents a barrier to foreign-investment activities and antitrust enforcement in other nations - where institutional support for FDI openness and strong antitrust are less evident - may also represent a deterrent to inward-FDI activity. My findings yield normative public-policy implications with respect to antitrust policy and the encouragement of inward-FDI activities. The finding of a negative relationship between antitrust enforcement and inward FDI is consistent with protectionist norms and values best characterizing the conduct of U.S. antitrust enforcement. While this protectionism in effect can discourage FDI, policymakers may implement a less strict antitrust enforcement (i.e., openness norms) to attract FDI.

\section{(3) HOW DOES ANTITRUST ENFORCEMENT AFFECT FOREIGN PRESENCE IN THE LOCAL M\&A MARKETS?}

My third essay ${ }^{3}$ examines how antitrust enforcement affects foreign presence in local M\&A markets. Also motivated by the potential for antitrust policy to involve protectionism, I ground my conceptual development focusing on the relevance of political risk and uncertainty in foreign-investment decisions and formulate that antitrust enforcement deters foreign-acquirer participation in local M\&A markets

\footnotetext{
1 There exists debates regarding the relationship between antitrust policy and foreign investments. Some scholars (e.g., Bris, Brisley, \& Cabolis, 2008; Oliveira, Hochstetler, \& Kalil, 2001) find antitrust enforcement to encourage inward FDI as well-run antitrust policy establishes a level playing field for all competitors and foreign investors who generally suffer from liability of foreignness could benefit even more. Yet other scholars consider antitrust enforcement to be protectionist in nature (e.g., Conybeare \& Kim, 2010; Dinc \& Erel, 2013) given that governments prefer domestically-owned entities to protect local business. Essays 2 and 3 further discuss this potential deterrence effect of antitrust enforcement.

2 Former Republican President Trump's “America first” agenda also implemented different policies and actions that targeted and deterred foreign investment activities. However, as former President Trump took office in January 2017, his presidency was beyond this study's time slope.

3 Published at the Journal of International Business Studies (Clougherty \& Zhang, 2021).
} 
(Kobrin, 1979).

Firms generally react to political risks and uncertainties, which arise from the governments' interference or prevention of business transactions, by reducing their investment willingness as the option value of delaying investment becomes higher under such risks and uncertainties. While political hurdles and hazards can negatively influence investment activities of all firms, foreign firms are generally more sensitive to such shocks. Considering the ability of merger control to manifest policy risk and uncertainty, foreign acquirers might be disproportionately deterred from engaging in acquisitions as compared to domestic acquirers when antitrust-policy risk and uncertainty increase.

I test my two theoretical priors by employing sector-level data on antitrust enforcement and foreign-acquirer presence in U.S. M\&A markets over the 2002-2017 period. My results indicate foreign acquirers are disproportionally deterred by antitrust-policy risk and uncertainty as compared to domestic acquirers. Specifically, increases in antitrustpolicy risk and antitrust-policy uncertainty lead to a reduced foreign-acquirer presence in the U.S. markets for corporate control.

Empirical evidence suggests that foreign-investment activities are more adversely affected by antitrust enforcement than domestic-investment activities. Protectionist U.S. antitrust policy contradicts the spirit behind the consumer-welfare criterion that is written and codified into U.S. antitrust law. Yet I should underscore that my empirical results simply indicate the antitrust enforcement is protectionist in effect, as foreign investors are disproportionately deterred by higher levels of antitrust risk and uncertainty. Given the protectionism in effect of U.S. antitrust policy, MNEs may reconsider the location-choice or entry-mode (which will be discussed in essay 4) decisions when enforcement increases.

\section{(4) HOW DOES ANTITRUST ENFORCEMENT AFFECT CROSS-BORDER HORIZONTAL M\&AS, NON-HORIZONTAL M\&AS, AND GREENFIELD FDI DIFFERENTLY?}

My last essay ${ }^{4}$ examines how antitrust enforcement affects cross-border non-horizontal M\&As and Greenfield FDI. This study extends previous essays by investigating how antitrust policy influences other modes of foreign investments. If MNEs have secondary incentives such as resourceseeking or access to local closely-tied networks (e.g., keiretsu) through M\&As in addition to the initial marketpower incentives, they are more likely to alter their horizontal investments to non-horizontal ones when facing increased antitrust deterrence effect. In contrast, MNEs are more likely to substitute Greenfield FDI for their cross-border horizontal M\&As when market-power is the main and critical incentive. Oftentimes, MNEs prefer cross-border horizontal M\&As to Greenfield FDI as a less costly option (Chang \& Rosenzweig, 2001); however, when horizontal transactions are deterred by antitrust enforcement, Greenfield FDI may become the preferred entry mode to pursue market-power incentives.

I test the theoretical priors by employing multi-level data on the industry-level U.S. antitrust enforcement, and firmlevel cross-border horizontal M\&As, cross-border non-horizontal M\&As, and Greenfield FDI in the U.S. markets over 2003-2017. The empirical results indicate that U.S. antitrust enforcement attracts Greenfield FDI with no effect on cross-border non-horizontal M\&As.

My findings support a substitutive relationship between cross-border horizontal M\&As and Greenfield FDI. It suggests when facing deterrence effect of antitrust enforcement, MNEs are more likely to achieve market-power by shifting to Greenfield FDI. The results also indicate no substitutive relationship between horizontal and non-horizontal M\&As. Although nonhorizontal M\&As are not the main targets of antitrust authorities, firms must still report their transactions for approval, which increases transaction costs. Moreover, MNEs with market-power incentives are less likely to alter their motivation to reduce transaction costs when facing stricter antitrust enforcement. Instead, they will shift to other entry modes or find alternative locations to achieve economies of scale.

\section{CONCLUSION}

My research has several implications for practitioners (i.e., managers, investors, government officials, etc.). My empirical results yield normative policy implications about the antitrust enforcement and the encouragement of inward-FDI activities. Most obviously, the results indicate it is lax (i.e., less strict) enforcement of merger control, which will generally encourage increased foreign-investment activities. Policymakers and government officials seeking to benefit from globalization may consider a less strict antitrust enforcement to attract FDI.

Moreover, finding a negative relationship between antitrust enforcement and FDI is consistent with U.S. antitrust policy disproportionately deterring foreign investors. Protectionist U.S. antitrust policy contradicts the spirit behind the consumer-welfare criterion and this protectionist effect would, in turn, contribute to de-globalization. MNEs need to consider protectionism in U.S. antitrust policy when making location-choice decisions.

Lastly, my dissertation shows that foreign investors deterred from horizontal acquisitions by increased antitrust enforcement would switch to Greenfield FDI . Greenfield investments offer the greatest control over the local affiliate, yet often require the longest time to establish, and the greatest contribution of know-how. However, most Greenfield FDI is horizontal by nature, and MNEs are not required to report Greenfield transactions to antitrust authorities. 
When M\&A antitrust policy becomes more stringent, market-power incentives decrease due to higher transaction costs of horizontal M\&As and Greenfield FDI becomes the main substitute for cross-border horizontal M\&As. For managers facing antitrust enforcement, Greenfield FDI can be the best alternatives to provide market power and cost reduction.

\section{ACKNOWLEDGMENTS}

I wish to thank John Mezias (editor), one anonymous referee, Joseph Clougherty (my advisor), and my dissertation committee (James Barth, Joseph Mahoney, and Fiona Yao) for insightful comments and suggestions.

\section{ABOUT THE AUTHOR}

Nan Zhang (nzhang1@csustan.edu) is Assistant Professor of Management in the College of Business Administration at California State University, Stanislaus. Before receiving a Ph.D. from the University of Illinois at Urbana-Champaign, she earned a Master of Finance and MBA from Auburn University. Her research interests encompass international business and strategic management while focusing on firm internationalization activities and strategic responses to policy and institutional factors.

Submitted: August 28, 2021 EST, Accepted: November 10, 2021 EST 


\section{REFERENCES}

Antràs, P. 2021. De-globalization? Global value chains in the post-Covid-19 age. Presented at the 2021 ECB Forum: "Central Banks in a Shifting World." https://scholar.harvard.edu/antras/publications/de-gl obalisation-global-value-chains-post-covid-19-age.

Brewer, T. L. 1993. Governments, policies, market imperfections, and foreign direct investment. Journal of International Business Studies, 24(1): 101-120.

Bris, A., Brisley, N., \& Cabolis, C. 2008. Adopting better corporate governance: Evidence from crossborder mergers. Journal of Corporate Finance, 14(3): 224-240.

Chang, S. J., \& Rosenzweig, P. M. 2001. The choice of entry mode in sequential foreign direct investment. Strategic Management Journal, 22(8): 747-776.

Clougherty, J. A., \& Zhang, N. 2021. Foreign investor reactions to risk and uncertainty in antitrust: U.S. merger policy enforcement and the deterrence of foreign acquirer presence. Journal of International Business Studies, 52(3): 454-478.

Conybeare, J., \& Kim, D. H. 2010. Barbarians at the gates: State control of global mergers and acquisitions. The World Economy, 33(9): 1175-1199.

Dinc, I. S., \& Erel, I. 2013. Economic nationalism in mergers and acquisitions. The Journal of Finance, 68(6): 2471-2514.
Kobrin, S. J. 1979. Political risk: A review and reconsideration. Journal of International Business Studies, 10(1): 67-80.

Kobrin, S. J. 2017. Bricks and mortar in a borderless world: Globalization, the backlash, and the multinational enterprise. Global Strategy Journal, 7(2): 159-171.

Oliveira, G., Hochstetler, R., \& Kalil, C. 2001.

Competition policy and foreign direct investment: Possible relationships and aspects from the recent Brazilian experience. Transnational Corporations, 10(1): 69-87.

Porter, M. E. 1998. Clusters and the new economics of competition. Harvard Business Review, 76(6): 77-90.

Viscusi, W. K., Vernon, J. M., \& Harrington, J. E. 1995. Economics of regulation and antitrust. Cambridge, MA: The MIT Press.

Zhang, N., \& Clougherty, J. A. Forthcoming. Crossborder acquisition and greenfield investment: Substitutes or complements? In D. R. King (Ed.), Acquisitions and Corporate Strategy: Alliances, Performance, and Divestment. London, U.K.: Routledge Publishing.

Zhang, X., \& Zhang, V. Y. 2010. Chinese merger control: Patterns and implications. Journal of Competition Law and Economics, 6(2): 477-496. 